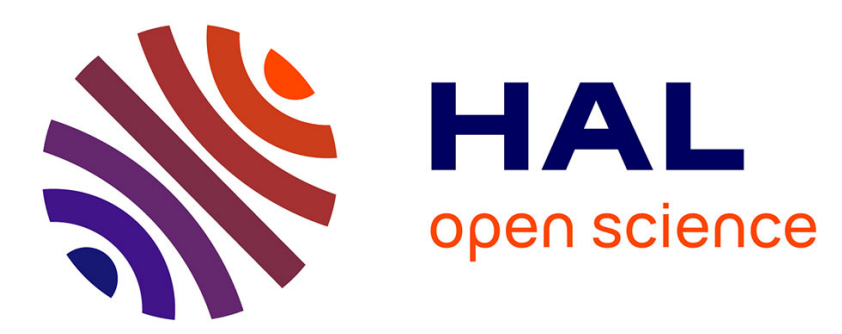

\title{
Comparative sensitivity to the fungicide tebuconazole of biofilm and plankton microbial communities in freshwater ecosystems
}

Joan Artigas, N. Pascault, Agnes Bouchez, J. Chastaine, D. Debroas, J.F. Humbert, J. Leloup, R.D. Tadonleke, A. ter Halle, S. Pesce

\section{To cite this version:}

Joan Artigas, N. Pascault, Agnes Bouchez, J. Chastaine, D. Debroas, et al.. Comparative sensitivity to the fungicide tebuconazole of biofilm and plankton microbial communities in freshwater ecosystems. Science of the Total Environment, 2014, 468-469, pp.326-336. 10.1016/j.scitotenv.2013.08.074 . hal$00995683 \mathrm{v} 2$

\section{HAL Id: hal-00995683 \\ https://hal.science/hal-00995683v2}

Submitted on 16 Mar 2015

HAL is a multi-disciplinary open access archive for the deposit and dissemination of scientific research documents, whether they are published or not. The documents may come from teaching and research institutions in France or abroad, or from public or private research centers.
L'archive ouverte pluridisciplinaire HAL, est destinée au dépôt et à la diffusion de documents scientifiques de niveau recherche, publiés ou non, émanant des établissements d'enseignement et de recherche français ou étrangers, des laboratoires publics ou privés. 
Science of The Total Environment Volumes 468-469, 15 January 2014, Pages 326-336

doi:10.1016/j.scitotenv.2013.08.074

Received 24 June 2013, Revised 23 August 2013, Accepted 23 August 2013, Available online 15 September 2013- Editor: Damia Barcelo

\title{
Comparative sensitivity to the fungicide tebuconazole of biofilm and plankton microbial communities in freshwater ecosystems
}

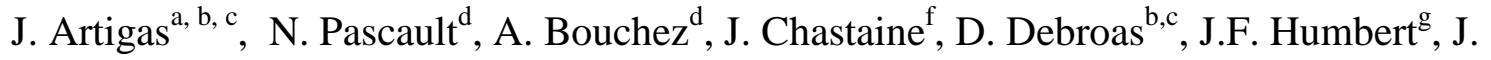 \\ Leloup $^{\mathrm{g}}$, R.D. Tadonleke ${ }^{\mathrm{d}}$, A. ter Halle ${ }^{\mathrm{e}, \mathrm{f}}$, S. Pesce ${ }^{\mathrm{a}}$ \\ a Irstea, UR MALY, 3 bis quai Chauveau, CP 220, 69336 Lyon, France \\ b Clermont Université, Université Blaise Pascal, Laboratoire "Microorganismes: Génome et Environnement", \\ BP 10448, 63000 Clermont-Ferrand, France \\ c CNRS, UMR 6023, LMGE, 63177 Aubière, France \\ d INRA, UMR CARRTEL, 75 Avenue Corzent, 74200 Thonon-les-Bains, France
}

e Clermont Université, Université Blaise Pascal, Laboratoire de Photochimie Moléculaire et Macromoléculaire (LPMM), BP 10448, 63000 Clermont-Ferrand, France

f CNRS, UMR 6505, LPMM, 63171 Aubière, France

g INRA, UMR BIOEMCO, Site de l'ENS, 46 rue d'Ulm, 75005 Paris, France

\section{Highlights}

- Biofilm and plankton microbial communities were exposed to Tebuconazole (TBZ).

- TBZ had effects on biofilm function including respiration and photosynthetic activity.

- Biofilm communities from polluted sites exhibited induced tolerance to TBZ.

- Plankton communities responded to TBZ by increasing bacterial cell densities.

- $\quad$ TBZ toxicity depends on the nature of microbial communities and pre-exposure to TBZ.

\section{Abstract}

Stream and lake ecosystems in agricultural watersheds are exposed to fungicide inputs that can threaten the structure and functioning of aquatic microbial communities. This research analyzes the impact of the triazole fungicide tebuconazole (TBZ) on natural biofilm and plankton microbial communities from sites presenting different degrees of agricultural contamination. Biofilm and plankton communities from less-polluted (LP) and polluted (P) sites were exposed to nominal concentrations of 0 (control), 2 and $20 \mu \mathrm{g}$ TBZ L- 1 in 3-week microcosm experiments. Descriptors of microbial community structure (bacterial density and chlorophyll-a concentration) and function (bacterial respiration and production and photosynthesis) were analyzed to chart the effects of TBZ 
and the kinetics of TBZ attenuation in water during the experiments. The results showed TBZ-induced effects on biofilm function (inhibition of substrate-induced respiration and photosynthetic activity), especially in LP-site communities, whereas plankton communities experienced a transitory stimulation of bacterial densities in communities from both LP and P sites. TBZ attenuation was stronger in biofilm (60-75\%) than plankton (15-18\%) experiments, probably due to greater adsorption on biofilms. The differences between biofilm and plankton responses to TBZ were likely explained by differences in community structure (presence of extracellular polymeric substances (EPS) matrix) and microbial composition. Biofilm communities also exhibited different sensitivity levels according to their in-field pre-exposure to fungicide, with P-site communities demonstrating adaptation capacities to TBZ. This study indicates that TBZ toxicity to non-targeted aquatic microbial communities essentially composed by microalgae and bacteria was moderate, and that its effects varied between stream and lake microbial communities.

\section{Keywords}

Algae; Bacteria; Fungicide; Photosynthetic efficiency; Adaptation; Substrate-induced respiration

\section{Introduction}

Freshwater ecosystems in agricultural watersheds are widely exposed to multiple pesticidecontamination events, including fungicides which pose major ecotoxicological threats to aquatic microbial community biodiversity and function (e.g. Montuelle et al., 2010 and Rasmussen et al., 2012a). The intensive use of modern azole fungicides like fluconazole, propiconazole and tebuconazole (TBZ) ( Richardson, 2009) has prompted studies aiming to understand their effects on aquatic detritivores and microbial decomposers ( Bundschuh et al., 2011 and Rasmussen et al., 2012b). TBZ has been found in numerous freshwater ecosystems in Europe, including rivers and lakes, and is reported as relatively persistent even after wastewater treatment ( Berenzen et al., 2005 and Kahle et al., 2008).

The main aquatic microbial communities potentially threatened by TBZ are fungi. TBZ affects fungal activity-related processes such as litter decomposition (Rasmussen et al., 2012b and Bundschuh et al., 2011) and inhibits ergosterol biosynthesis, which hampers fungal mycelium growth (Copping and Hewitt, 1998). Exposing submerged leaves to TBZ led to lower fungal biomass accumulation and reduced the ability of microorganisms to decompose cellulose and hemicellulose compounds (Artigas et al., 2012). Important bacterial groups such as nitrogen-fixing and nitrifying bacteria can also be directly or indirectly affected by fungicides (Johnsen et al., 2001). Specifically, TBZ has been reported to stimulate ammonifying bacteria populations at early exposure in soils and nitrifying bacteria in later exposure phases (Chen et al., 2001, Cycoń et al., 2006 and Muñoz-Leoz et al., 2011). This stimulating effect on bacterial groups could be associated with increased levels of nutrients and energy sources released from dead fungal hyphae killed by TBZ (Cycon et al., 2006) or by chemicals present in the fungicide formulation becoming available to bacteria (Muñoz-Leoz et al., 2011). Although such results suggest that similar effects will be found in aquatic ecosystems, with consequences on microbial processes, only a few studies have explored the effects of TBZ on aquatic microbial communities other than fungi in biofilms and plankton (Tlili et al., 2011a and Artigas et al., 2012).

Microbial community exposure to TBZ varies between stream and lake ecosystems. Pesticide mobilization in agricultural watersheds mostly depends on drift, run-off and drainage processes from the watershed (Kolpin et al., 1996), and often coincides with fungicide applications in conjunction with cultural practices (Rabiet et al., 2010). However, the arrival of fungicides into surface water 
depends on watershed topography (especially field slope), soil characteristics (i.e. organic carbonwater binding coefficient), and the half-life of the molecule (49-610 days for TBZ in aerobic soils; Strickland et al., 2004). Once in the aquatic ecosystem, hydrological conditions in lotic ecosystems mostly generate peak exposure scenarios (lasting a few hours to days) at high contaminant concentrations, whereas lentic ecosystems establish a more chronic exposure scenario (several months) at lower contaminant concentration ( Simmons and Wallschlager, 2005). Consistently with this pattern, TBZ concentrations recorded in rivers (often at $\mu \mathrm{g} \mathrm{L}-1$ ) exceed those found in lakes (often at ng L- 1; Richardson, 2009, Rabiet et al., 2010 and Kahle et al., 2008). However, TBZ concentrations in rivers are highly variable over time ( Rabiet et al., 2010) and chronic exposure scenarios to low fungicide concentrations can also be detected (i.e. Reilly et al., 2012). Knowing that level and duration of exposure of microbial communities to the pesticide are important factors determining the adaptation processes of microorganisms ( Le Jeune et al., 2007 and Pesce et al., 2009), microbial communities from stream biofilms and lakes are likely to display contrasted susceptibility to this fungicide.

Comparative studies assessing pollutant toxicity between lotic (stream) and lentic (lake) ecosystems are rare in the literature (Munawar et al., 1999 and Simmons and Wallschlager, 2005), despite their potential utility for better understanding how the ecological, hydrological and biogeochemical characteristics of each type of ecosystem can modulate pollutant ecotoxicity. In this global framework, we adopted an experimental approach to investigate the effects of TBZ on non-targeted microalgal and bacterial communities living in stream biofilms and lake plankton samples collected in natural ecosystems. For each ecosystem (stream and lake), samples were collected in sites qualified as "less polluted" and "polluted" based on previous in situ measurements in order to assess the influence of pre-exposure to TBZ on their susceptibility to the fungicide. The responses of all these communities to TBZ (at two doses, 2 and $20 \mu \mathrm{g}$ TBZ L- 1) were examined using a range of structural and functional descriptors. This experimental scheme was thus designed to test the respective effects of community lifestyle (benthic versus planktonic) and pre-exposure to the pollutant on the responses of non-targeted aquatic microbial communities to TBZ.

\section{Materials and methods}

\subsection{Biological communities}

Biofilm and plankton microbial communities from less-polluted (LP) and polluted (P) sites were obtained from stream and lake ecosystems in eastern France. Biofilms were obtained from two sites (upstream in Saint Joseph and downstream in Saint Ennemond) of Morcille River (Beaujolais vineyard region, $46.15^{\circ} \mathrm{N} 4.60^{\circ} \mathrm{E}$ ), a siliceous stream composed by three nested sub-watersheds that experiences an upstream-to-downstream gradient of agricultural contamination (Rabiet et al., 2010 and Montuelle et al., 2010). This pollution gradient is characterized by increases in dissolved organic carbon, phosphate (125\% to $300 \%$ increase between upstream and downstream sites, respectively) and copper, arsenic, herbicide (diuron and its breakdown products) and fungicide (azoxystrobin, carbendazim, tebuconazole, procymidone and dimetomorph) concentrations (Montuelle et al., 2010). Previous surveys have shown that TBZ concentrations ranged from $0.001-0.1 \mu \mathrm{g} \mathrm{L}-1$ at the upstream LP site of Saint Joseph to 0.01-4 $\mu \mathrm{g} \mathrm{L-} 1$ at the downstream P site of Saint Ennemond (Margoum C., pers. comm.). Artificial glass substrata ( $20 \mathrm{~cm} 2$ tiles) were left to colonize for one month at both study sites. Biofilm colonization was conducted during late summer, when the highest TBZ contamination peaks had been detected at the P site (Montuelle et al., 2010). The resulting biofilms from LP and P sites were collected, transported cold $\left(4{ }^{\circ} \mathrm{C}\right)$ to the laboratory, and placed in indoor stream channels for TBZ experiments. 
Plankton communities were obtained from two different peri-alpine lakes experiencing contrasting degrees of agricultural contamination - one less polluted (Lake Aiguebelette, mean TBZ concentration $<0.001 \mu \mathrm{g} \mathrm{L}-1$ ) and one polluted (Lake Geneva, mean TBZ concentration $=0.001 \mu \mathrm{g}$ L- 1). Lake Aiguebelette (LP site) is situated in a small forested watershed $(70 \mathrm{~km} 2)$ bearing low anthropogenic pressure, whereas Lake Geneva ( $\mathrm{P}$ site) has a much larger watershed $(7395 \mathrm{~km} 2)$ bearing high pressure due to urbanization and agriculture. Samples (400 L) from each lake were collected from the $0-50 \mathrm{~cm}$ layer and filtered through a $50 \mu \mathrm{m}$ pore-size filter to remove zooplankton. Samples were collected at a central part in each lake (Lake Aiguebelette: $5^{\circ} 47^{\prime} 56^{\prime \prime}, 45^{\circ} 33^{\prime} 02^{\prime \prime}$, Lake Geneva: 6 $\left.35^{\prime} 34^{\prime \prime}, 46^{\circ} 27^{\prime} 22^{\prime \prime}\right)$. Samples with plankton communities from LP and P sites were transported in plastic containers, stored overnight at $4{ }^{\circ} \mathrm{C}$, and used for subsequent TBZ experiments in indoor microcosms.

\subsection{Laboratory experiments}

The experiments were performed in glass indoor stream channels $(\mathrm{L} \times \mathrm{W} \times \mathrm{D}=63 \mathrm{~cm} \times 11 \mathrm{~cm} \times 4$ $\mathrm{cm})$ for biofilms and in transparent polycarbonate bottles $(20 \mathrm{~L})$ for plankton. Each type of microbial community (LP-site biofilm, P-site biofilm, LP-site plankton, P-site plankton) was subjected to three different treatments consisting of control (non-contaminated), low-TBZ dose (2 $\mu \mathrm{g} \mathrm{L}-1)$ and highTBZ dose $(20 \mu \mathrm{g} \mathrm{L}-1)$ exposure.

For biofilms, each microbial community (LP and P sites) and treatment was tested in three independent channel replicates (18 channels in total), each connected to a separate $5 \mathrm{~L}$ reservoir (Pyrex, USA) by means of an aquarium pump (NEWA MJ 750). Water temperature was set to $20{ }^{\circ} \mathrm{C}$ and flow conditions were set to $0.19 \mathrm{~L} \mathrm{~s}-1$, all under a $12 \mathrm{~h} / 12 \mathrm{~h}$ light/dark cycle. Before TBZ contamination, stream biofilms were allowed to adapt for one week to the indoor channels by recirculating tap water (previously dechlorinated using an active carbon filter). After TBZ contamination, the water was not replaced during the 22-day experiment but $\mathrm{N}$ and $\mathrm{P}$ were added to prevent nutrient limitation in the biofilms (weekly added quantities: $225 \mu \mathrm{g} \mathrm{N} \mathrm{L}-1$ and $65 \mu \mathrm{g} \mathrm{P} \mathrm{L}-1$ ). For plankton, LP and P-site communities were exposed to the three different treatments in triplicate. Bottles containing plankton communities (18 in total) were incubated at $20{ }^{\circ} \mathrm{C}$ under a $12 \mathrm{~h} / 12 \mathrm{~h}$ light/dark cycle and without nutrient addition. Air circulation was supplied to prevent anoxia in the plankton communities.

Solutions of TBZ (C16H22CIN3O, Sigma Aldrich; $10 \mathrm{mg} \mathrm{L}-1$ in deionized water) were added to the biofilm and plankton communities, and biological community and water samples were taken on days $0,3,7,10,14,17,22$ post addition. For biofilms, samples were scraped from glass tiles and suspended in the water of the corresponding channel for subsequent biological analyses. Plankton samples were taken with a pipette directly from bottles after stirring. Assays to determine substrate-induced respiration, bacterial production, chlorophyll concentration and photosynthetic activity were processed immediately after sampling, while samples taken to determine bacterial density were fixed in $2 \%$ formaldehyde until analysis. Water samples to determine nutrient concentrations were taken into glass flasks $(100 \mathrm{~mL})$ and analyzed immediately. Further water samples taken to analyze TBZ concentration $(100 \mathrm{~mL})$ and TBZ metabolites $(500 \mathrm{~mL})$ were stored frozen $\left(-20^{\circ} \mathrm{C}\right)$ until analysis. 


\subsection{Chemical analyses}

Water temperature and $\mathrm{pH}$ were measured at each sampling time using portable meters (WTW 3110, Germany). Filtered $(0.45 \mu \mathrm{m})$ water samples were analyzed to determine the concentration of inorganic nutrients [soluble reactive phosphorus (SRP), dissolved inorganic nitrogen (DIN = ammonia + nitrite + nitrate) and dissolved organic carbon (DOC)] following French standard operating procedures.

TBZ quantification was determined by UPLC (ACQUITY, Waters, Manchester, UK) using a Hypersil Gold PFP stationary phase $(100 \mathrm{~m} \times 2.1 \mathrm{~mm} \times 1.9 \mu \mathrm{m})$ with detection at $220 \mathrm{~nm}$. The mobile phase consists of $50 \%$ acetonitrile $/ 50 \% \mathrm{H} 2 \mathrm{O}$ at $0.5 \mathrm{~mL} / \mathrm{min}$. Analysis was performed at $30{ }^{\circ} \mathrm{C}$ with an injection volume of $6 \mu \mathrm{L}$. TBZ degradation metabolites were determined by LC/Q-TOF (Waters/Micromass, Manchester, UK). For metabolite analyses, $25 \mu \mathrm{L}$ were injected onto a reversephase column (X terra, Waters, $\mathrm{C} 18,3.5 \mu \mathrm{m}, 100 \mathrm{~mm} \times 2.1 \mathrm{~mm}$ ) at a flow rate of $0.3 \mathrm{~mL}$ min- 1 with a mobile phase composed of acetonitrile (solvent $\mathrm{A}$ ) and acidified water (solvent $\mathrm{B}$ : formic acid $0.3 \%$ $\mathrm{v} / \mathrm{v} ; \mathrm{pH}$ 2.6). The gradient was 5\% A from 0-5 min, 5-95\% A (linear) from 5-15 min, and 95\% A from 15-25 min. The desolvation chamber and ion source block temperatures were set at $350{ }^{\circ} \mathrm{C}$ and $100{ }^{\circ} \mathrm{C}$, respectively. The voltages for the probe and ion source components were set to $2.1 \mathrm{kV}$ for the stainless steel capillary, $35 \mathrm{~V}$ for the sample cone, and $2 \mathrm{~V}$ for the extractor cone. A collision energy gradient $(15-35 \mathrm{eV})$ was used for preliminary fingerprints, and specific energies of $15-45 \mathrm{eV}$ were used to unambiguously assign the MS/MS fragments.

\subsection{Biological analyses}

\subsubsection{Bacterial density}

Bacterial densities were quantified by DAPI staining for biofilms (Porter and Feig, 1980) and by flow cytometry for plankton communities (Tadonléké et al., 2005). For biofilms, suspensions corresponding to $1 \mathrm{~cm} 2$ of scraped biofilm were sonicated for $2 \mathrm{~min}$ to facilitate disaggregation, diluted 1:2, and stained for $5 \mathrm{~min}$ with 4,6-diamidino-2-phenylindole (DAPI, Sigma-Aldrich) at a final concentration of $2 \mu \mathrm{g} \mathrm{mL}-1$. Suspensions were then filtered through $0.2 \mu \mathrm{m}$ irgalan black-stained polycarbonate membranes (Nuclepore, Whatman, England) and mounted on microscope slides. Fifteen fields were counted per filter, accounting for a total of 400-800 cells, using a fluorescence microscope (Nikon Labophot-2, Japan) at $1000 \times$ magnification. Bacterial densities were calculated as cells per unit of biofilm surface area in $\mathrm{cm} 2$.

For biofilms, additional bacterial suspensions $(1 \mathrm{~cm} 2$ of biofilm surface area) were diluted 1:2 and stained with propidium iodide (PI) and SYTO $9^{\mathrm{TM}}$ (BacLight) for $15 \mathrm{~min}$ at room temperature in the dark. Samples were subsequently filtered through $0.2 \mu \mathrm{m}$ irgalan black-stained polycarbonate membranes and mounted on microscope slides. Counting of dead (red-stained) and live (greenstained) bacterial cells was performed on 20 random microscope fields using an epifluorescence microscope (Nikon Labophot-2, Japan) at $1000 \times$ magnification ( Freese et al., 2006). The ratio between live and dead bacterial cells (L/D bacterial ratio) was calculated.

For plankton, total bacterial abundance was determined using a flow cytometer (FacsCalibur, BectonDickinson) equipped with a laser emitting at $488 \mathrm{~nm}$. Samples were stained with SYBR Green II (Invitrogen), and an internal standard (yellow-green $0.92 \mu \mathrm{m}$ fluorescent latex beads) was included. Samples were run at low speed (10-12 $\mu \mathrm{L}$ min- 1), and bacterial abundances were calculated as cells $\mathrm{mL}-1$. 


\subsubsection{Bacterial activity}

Bacterial activity in biofilms was estimated using substrate-induced respiration assays (Campbell et al., 2003) as modified by Tlili et al. (2011b). Bacterial activity in plankton was estimated by means of bacterial production using 3H-leucine incorporation assays (Tadonléké et al., 2005). For biofilms, deep-well microtiter plates were filled with biofilm suspensions $(500 \mu \mathrm{L})$ of the corresponding treatment, and $30 \mu \mathrm{L}$ of glucose $(6.2 \mathrm{mg} \mathrm{C}$ per well) was added. Controls without glucose were also included to determine basal respiration. Immediately after inoculation, the detection microplate (containing cresol red dye) was sealed to the deep-well plate with a silicone seal. The assembled MicroResp system was incubated in the dark at room temperature for $15 \mathrm{~h}$. After incubation, detection microplate absorbance was measured at $590 \mathrm{~nm}$ (Biotek Synergy HT spectrophotometer), amounts of released $\mathrm{CO} 2$ were calculated, and the results were expressed in $\mu \mathrm{g} \mathrm{CO} 2 \mathrm{mgAFDW}-1 \mathrm{~h}-1$.

For plankton, bacterial production was estimated from $3 \mathrm{H}$-leucine (Leu) incorporation by bacteria after prior determination of saturating concentration (Tadonléké et al., 2005 and Tadonléké et al., 2009). The samples were counted in a scintillation counter (2100-TR, Packard Instruments). The results were expressed in pmol $[3 \mathrm{H}]$ leucine $\mathrm{L}-1 \mathrm{~h}-1$ incorporated.

\subsubsection{Chlorophyll-a concentration and photosynthetic activity}

"In vivo" measurements of chlorophyll-a fluorescence in biofilms and plankton communities were performed using the Phyto-PAM fluorometer (Heinz Walz, Germany). In dark-adapted communities (ca. $30 \mathrm{~min}$ ), Phyto-PAM excites chlorophyll fluorescence at different measuring lights (470, 520, 645 and $665 \mathrm{~nm}$ ), and the reading at $665 \mathrm{~nm}$ (F0) is proportional to chlorophyll-a concentration ( Rysgaard et al., 2001). Photosynthetic efficiency measurements were based on the maximal quantum yield (YII) of algae which reflects number of functional photosystem II ( Schreiber et al., 2002). A single saturation pulse was applied to calculate maximal quantum yield, which was later computed considering F0 (steady-state fluorescence) and Fm (maximum fluorescence after saturation pulse) parameters.

\subsection{Statistical analyses}

Three-way ANOVA tests were applied on biological descriptors and on water chemical characteristics to test differences between control and TBZ-contaminated treatments in LP and P-site communities over time. Biological descriptors were classified as functional (substrate-induced respiration, bacterial production, L/D cell ratio, photosynthetic efficiency) and structural (bacterial density and chlorophylla concentration). The sources of variation were calculated for Time (T), Treatment (control, 2 and 20 $\mu \mathrm{g} \mathrm{L}-1$ ) and Site (clean vs. polluted) and their corresponding interactions. Multiple comparison tests (Tukey test) were also applied on the three-way ANOVA to determine differences between treatments. Prior to all ANOVA analyses, biological and chemical variables were log-transformed and resultant probability values adjusted by the Dunn-Sidak correction. SPSS Statistics 17.0 was used for analyses.

The percentage of difference (D) of biological descriptors in TBZ treatments (Dtreatment) relative to controls (Dcontrol) was calculated using the following equation:

$$
\mathrm{D}(\%)=\frac{\mathrm{D}_{\text {treatment }}-\mathrm{D}_{\text {control }}}{\mathrm{D}_{\text {control }}} \times 100
$$




\section{Results}

\subsection{Physical and chemical characteristics of the water}

Water temperature and $\mathrm{pH}$ conditions were similar between biofilm (Temperature $=20.4-20.6$ and $\mathrm{pH}$ $=8.5-8.6)$ and plankton (Temperature $=20.5-20.9$ and $\mathrm{pH}=8.1-8.3$ ) TBZ experiments, whereas water nutrient concentrations (DOC, DIN and SRP) varied between samples from LP and P sites (biofilms and plankton) and between TBZ treatments (only biofilms) (Fig. 1, Table 1).

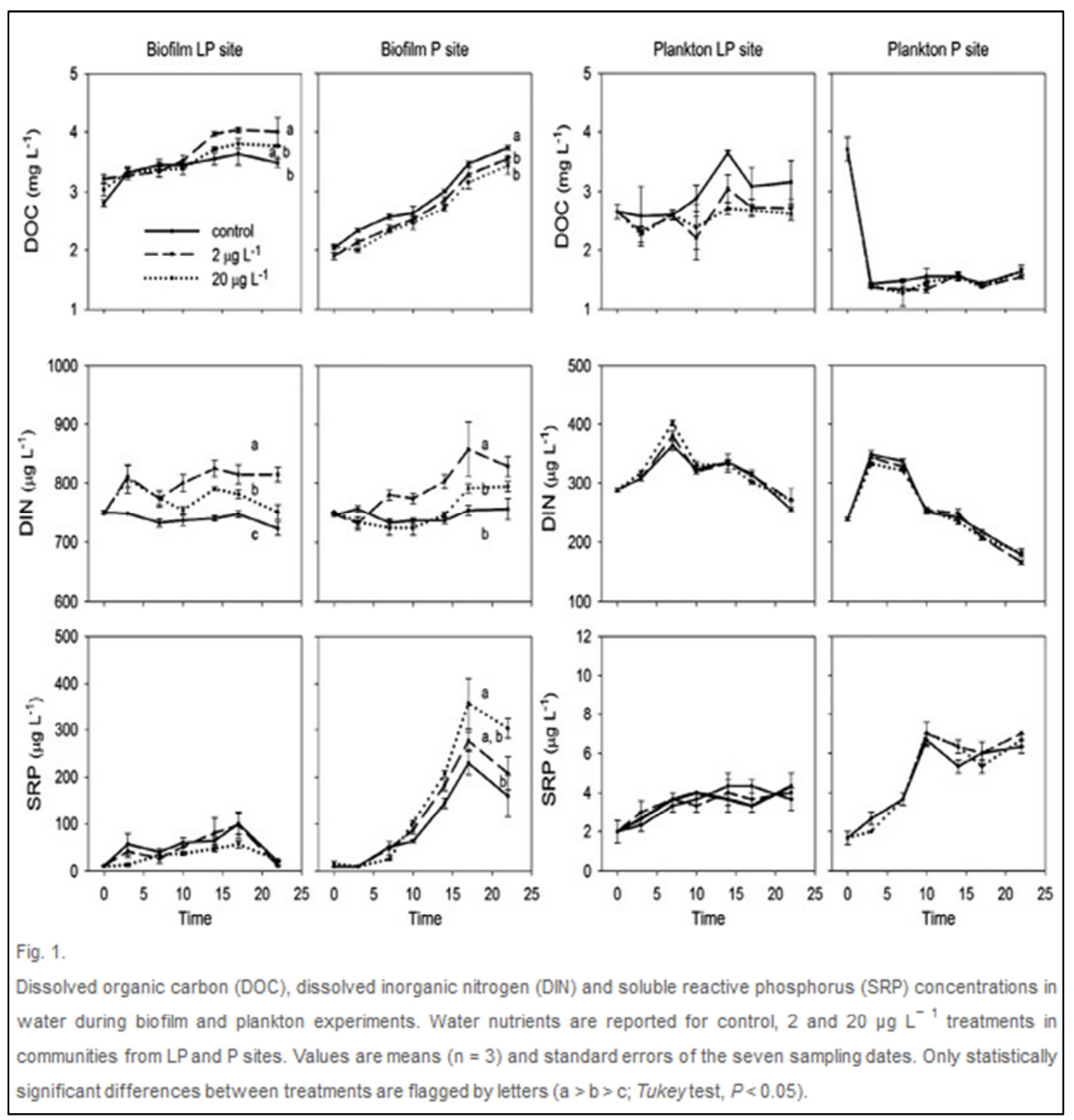

Water nutrient concentration comparisons between LP and P sites revealed that DOC concentration was greater in LP-site communities whereas SRP concentration was greater in P-site communities during the 22-day experiment (Fig. 1). Conversely, water DIN concentration was similar between LP and P-site biofilms but not LP and P-site plankton (average DIN in LP 313.4 $\pm 7.3 \mu \mathrm{g} \mathrm{L}-1$ and DIN in P $259 \pm 13 \mu \mathrm{g} \mathrm{L}-1$, Table 1). Water nutrient concentrations (especially SRP) tended to increase during experiments, except in P-site plankton communities where decreases of DOC ( $62 \%$ between Time 0 and Time 3 ) and DIN (-26\% between Time 3 and Time 22) concentrations were observed (Fig. 1). 


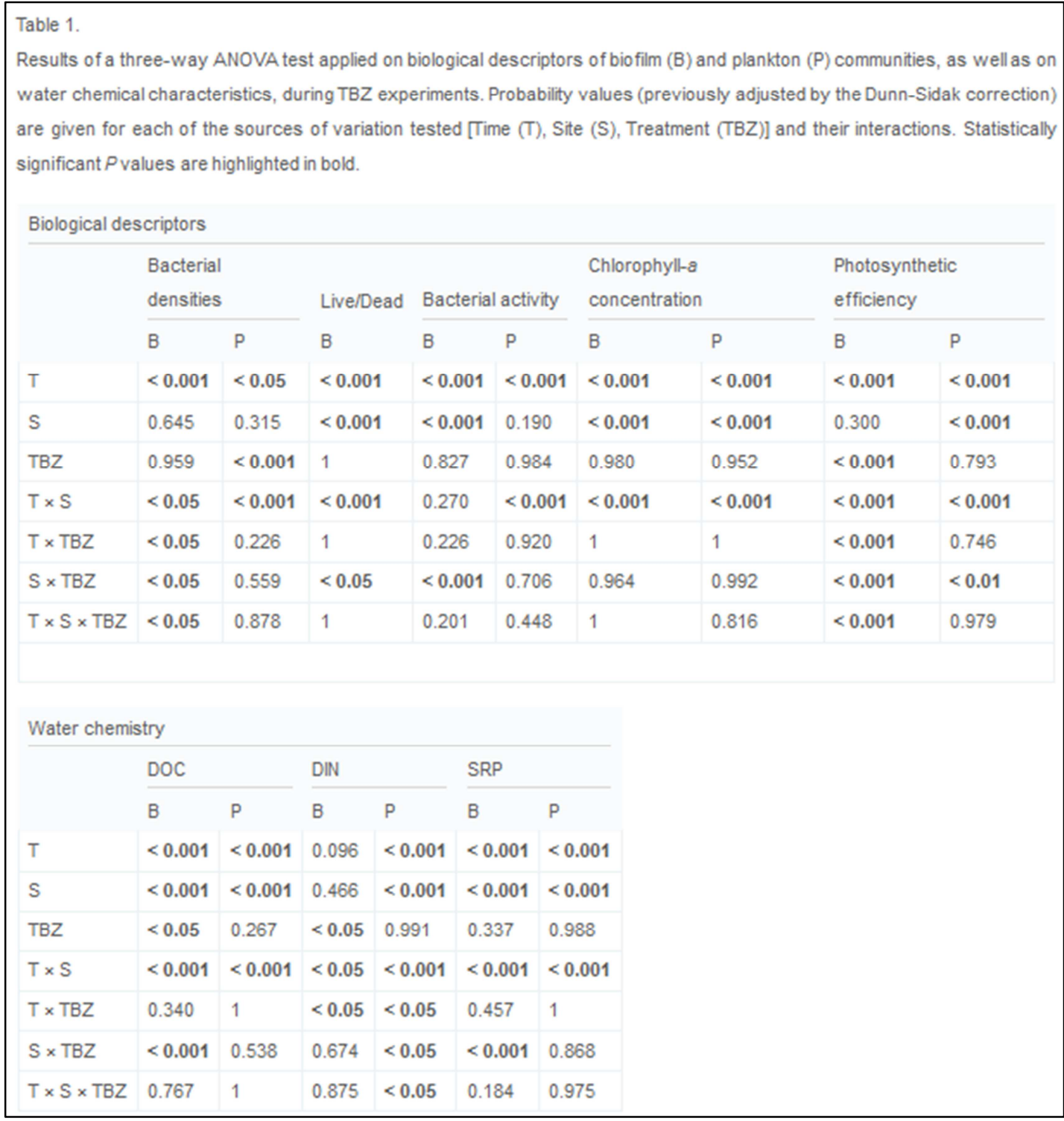

Water DOC, DIN and SRP concentrations varied between control and TBZ treatments in biofilm experiments but not in plankton experiments (Table 1). In biofilms, TBZ treatments (at 2 and $20 \mu \mathrm{g} \mathrm{L-}$ 1) had greater DOC, DIN and SRP concentrations in comparison to controls (except for SRP in LP, Tukey test, Fig. 1). Chronologically, the differences in nutrient concentrations between control and TBZ treatments for biofilms were observed first for DIN (Time 3) and later for DOC and SRP (Time 14) concentrations.

\subsection{TBZ concentrations}

TBZ concentration analyses in water (Fig. 2) confirmed the exposure of biofilm and plankton communities to low and high fungicide doses. TBZ concentrations at the beginning of experiments (Time 0) were $4.6 \pm 0.7 \mu \mathrm{g} \mathrm{L}-1$ (low dose) and $27.3 \pm 1.9 \mu \mathrm{g} \mathrm{L}-1$ (high dose) for biofilms, and $1.8 \pm$ $0.2 \mu \mathrm{g} \mathrm{L}-1$ (low dose) and $21 \pm 1.3 \mu \mathrm{g} \mathrm{L}-1$ (high dose) for plankton. TBZ concentrations decreased over the three-week experiment, revealing an attenuation of fungicide concentration in the water phase. However, this decrease was greater in biofilms (range $60-75 \%$ between Time 0 and Time 22) than in plankton communities (range 15-18\%). Secondary metabolites of TBZ, such as hydroxyltebuconazole and desbutyl-tebuconazole, were detected in water at the end of biofilm experiments (Time 22, data not shown). 


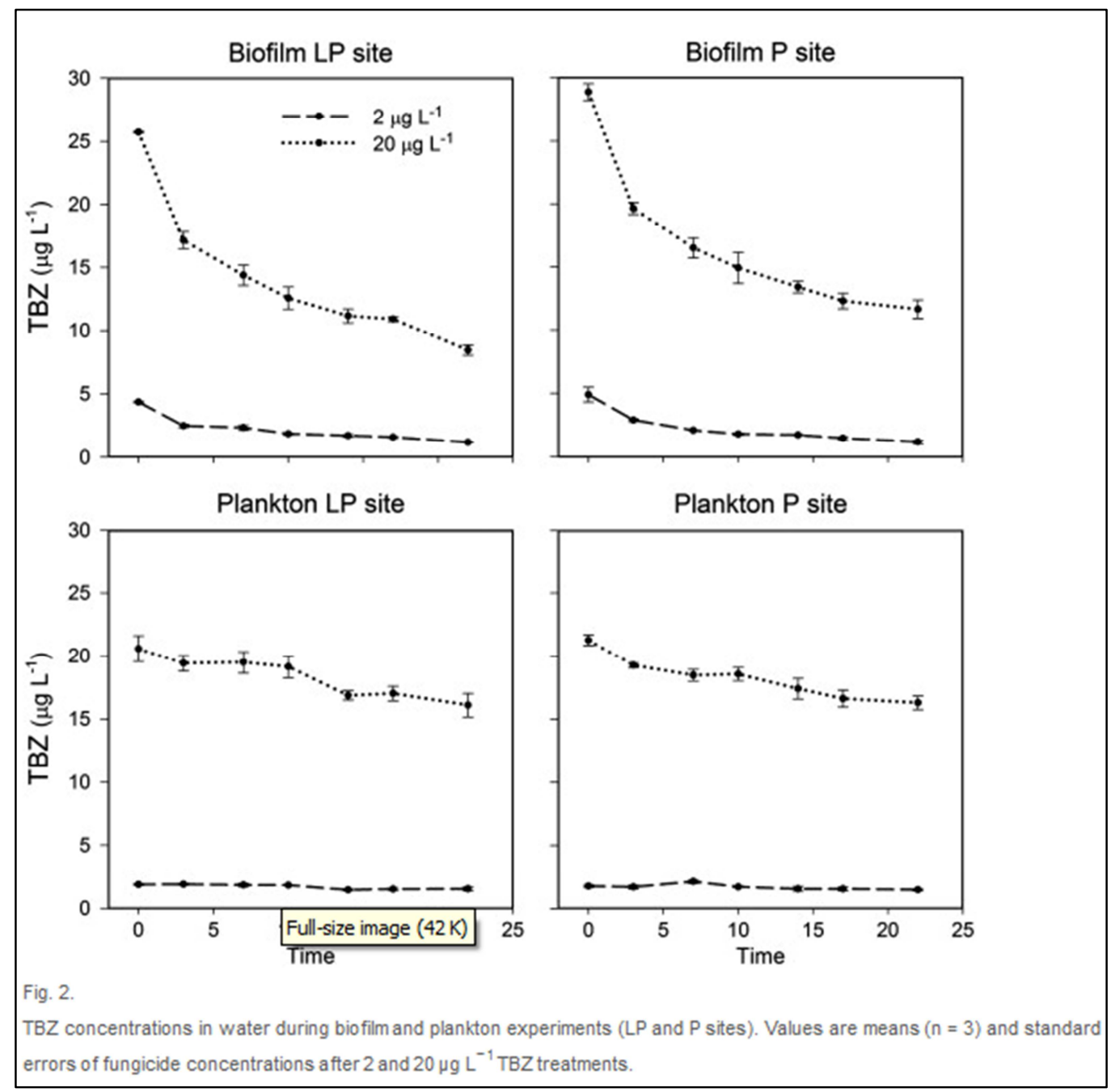

\subsection{Bacterial communities}

\subsubsection{Bacterial densities}

Bacterial densities at the beginning of the experiment (Time 0) were similar between LP-site $(3.2 \times$ 107 cells $\mathrm{cm}-2)$ and P-site $(3 \times 107$ cells $\mathrm{cm}-2)$ biofilms but different between LP-site $(3.4 \times 106$ cells L- 1) and P-site $(6.3 \times 106$ cells L- 1) plankton communities. Cell densities showed significant temporal variation in biofilm and plankton microcosm experiments, but only plankton communities were affected by TBZ (Table 1).

TBZ increased bacterial densities in plankton communities from the two studied sites (Fig. 3). The increases were globally stronger at the high TBZ dose $(+21 \%$ in LP-site plankton and $+48 \%$ in P-site plankton; Fig. 3, Tukey $\mathrm{P}<0.05$ ) but appeared relatively transient over time (weak differences at Time 22). TBZ effects on biofilm bacteria were also significant but were site- and time-dependent ( Table 1). While TBZ treatment resulted in increases in bacterial densities in LP-site biofilms at Time 3 and Time 6, it tended to decrease bacterial densities in P-site biofilms between Time 6 to Time 10.

L/D cell ratios (only available for biofilms) in the controls averaged 0.23 for the LP site and 0.31 for the $\mathrm{P}$ site between Time 0 and Time 22 (Fig. 4). The presence of TBZ led to different patterns of decrease in L/D cell ratios in communities from the LP and P sites (average $-48 \%$ and $-35 \%$, respectively) (Site $\times$ TBZ effect, Table 1). These effects on biofilm L/D cell ratios were fairly persistent over time and were constant between TBZ doses 

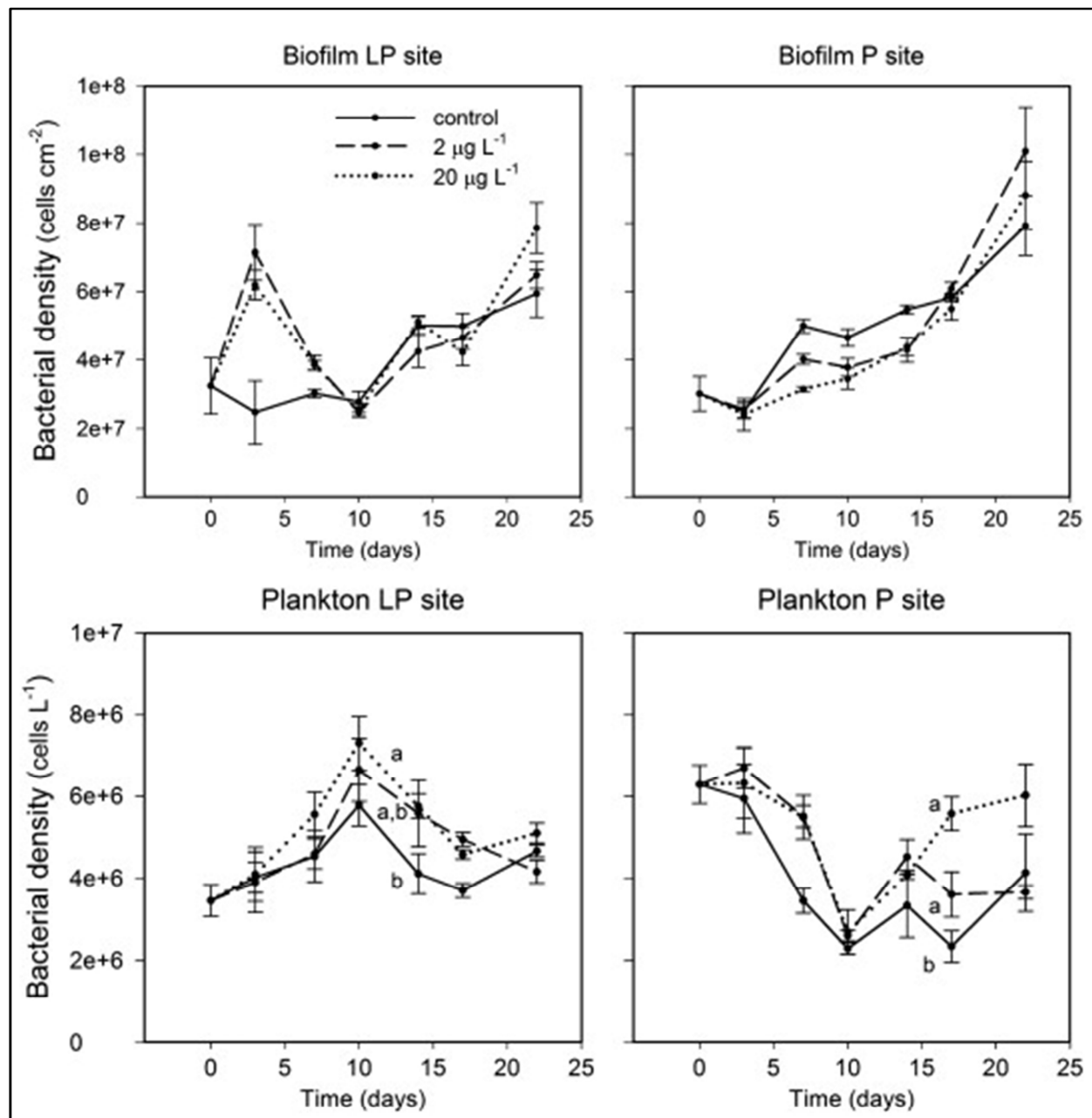

Fig. 3.

Bacterial densities in biofilm and plankton communities ( $L P$ and $P$ sites) during TBZ experiments. Results from biofilms (upper plots) and plankton (lower plots) communities subjected to control and TBZ treatments ( 2 and $20 \mu \mathrm{g} \mathrm{L}{ }^{-1}$ ) at the seven sampling dates are reported. Only statistically significant differences between treatments are flagged by letters $(\mathrm{a}>\mathrm{b}$; Tukey test, $P<0.05$ ).
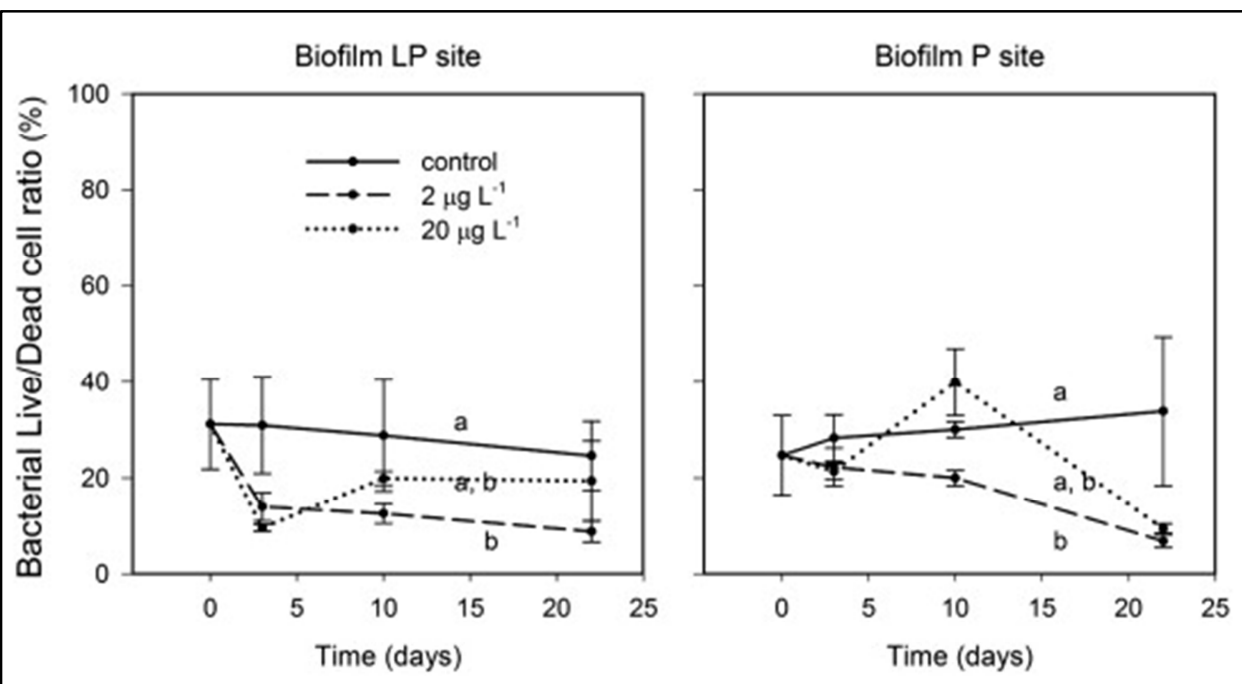

Fig. 4 .

Live/Dead bacterial cell ratios calculated in biofilms from LP and P sites during TBZ experiments. Values are means ( $n=3$ ) and standard errors of $L D$ ratios for the three treatments (control, $2 \mu \mathrm{g} \mathrm{L}^{-1}$ and $20 \mu \mathrm{g} \mathrm{L}^{-1}$ ) at Times $0,3,10$ and 22 days. Statistically significant differences between treatments are flagged by letters ( $\mathrm{a}>\mathrm{b}$; Tukey test, $P<0.05$ ). 


\subsubsection{Bacterial activity}

SIR rates measured in control biofilms from the two sites remained fairly constant over the experiment (1145 $\pm 117 \mathrm{mgCO} 2 \mathrm{mgAFDW}-1 \mathrm{~h}-1$, average Time 0-Time 22), except for a sharp decrease at Time 3, independently of TBZ exposure (Fig. 5). TBZ decreased SIR in LP-site biofilms (range: - 20 to $-28 \%$ ) compared to controls (Site $\times$ TBZ effect, Table 1). This negative effect was more intense between Time 10 and Time 17 and was independent of TBZ dose (Tukey test, $\mathrm{P}<0.05$, Fig. 5). Conversely, TBZ tended to stimulate SIR in P-site biofilms (range: +23 to $+48 \%$ ), but this effect was not statistically significant.

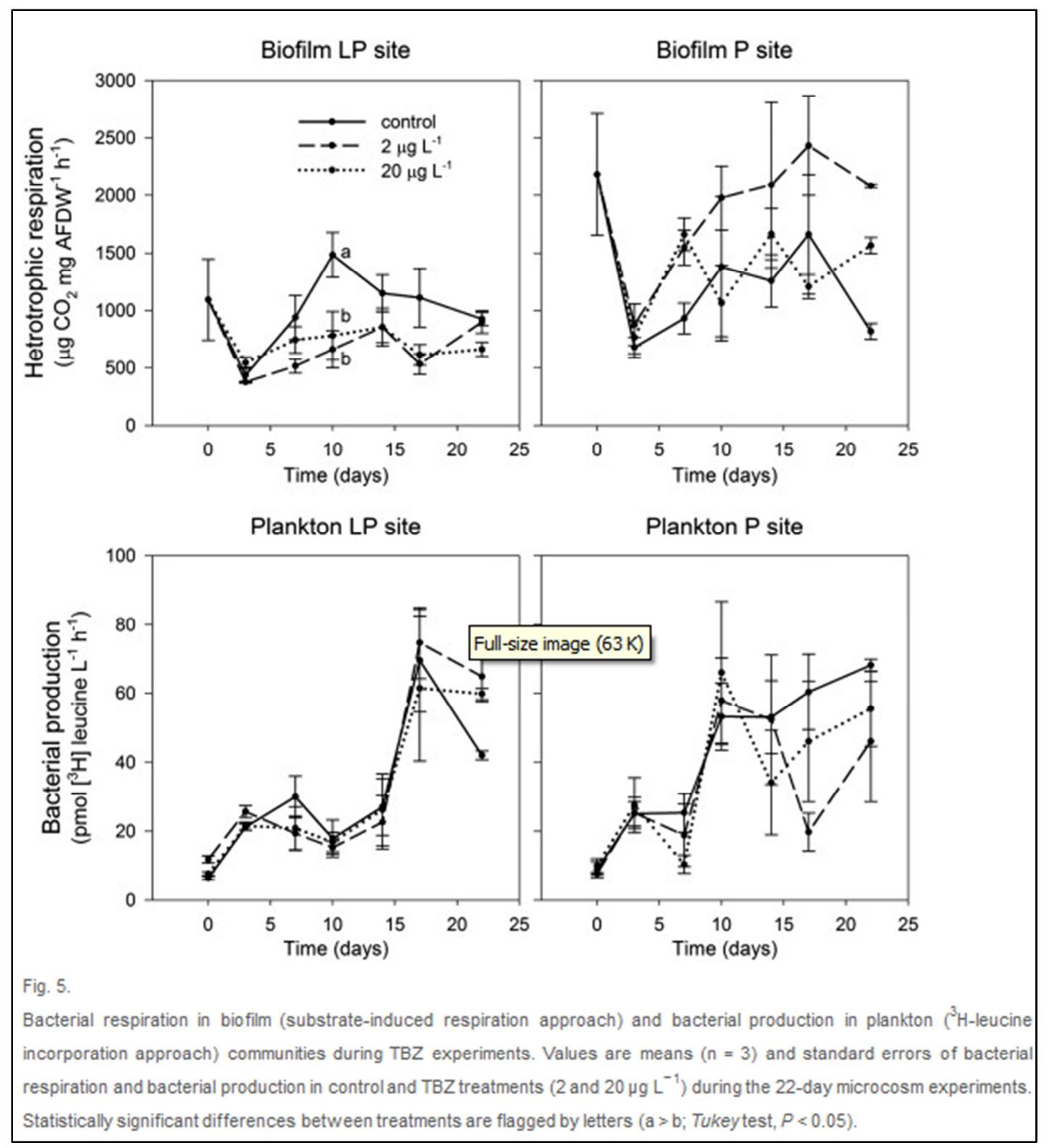

Bacterial production in plankton increased during the experiments but without an observable effect of TBZ (Table 1). Bacterial production in controls (including LP and P sites) ranged from 6-9 pmol [3H]leucine L- $1 \mathrm{~h}-1$ at Time 0 to 42-68 pmol [3H]leucine L- $1 \mathrm{~h}-1$ at Time 22. It was only at Time 22 (Fig. 5) when slight TBZ effects were observed in LP-site plankton communities (range: +40 to + $50 \%$ compared to controls). 


\subsection{Algal communities}

\subsubsection{Chlorophyll-a concentration}

Chlorophyll-a measurements in control treatments evidenced differences between biofilm and plankton LP and P-site communities ( Table 1). For biofilms, average chlorophyll-a concentration in controls was greater in the LP site $(82.7 \pm 5.6 \mu \mathrm{g} \mathrm{chl} \mathrm{cm-2)}$ than the P site $(39.2 \pm 3.9 \mu \mathrm{g} \mathrm{chl} \mathrm{cm-2)}$, whereas for plankton communities average chlorophyll-a concentration was greater in the P site $(35 \pm$ $4.8 \mu \mathrm{g}$ chl L- 1) than the LP site $(14.5 \pm 0.5 \mu \mathrm{g}$ chl L- 1). Chlorophyll-a values were not affected by TBZ in either biofilms or plankton ( Table 1), but showed significant temporal variations in the microcosms (Time $\times$ Site effect; Table 1 and Fig. 6).

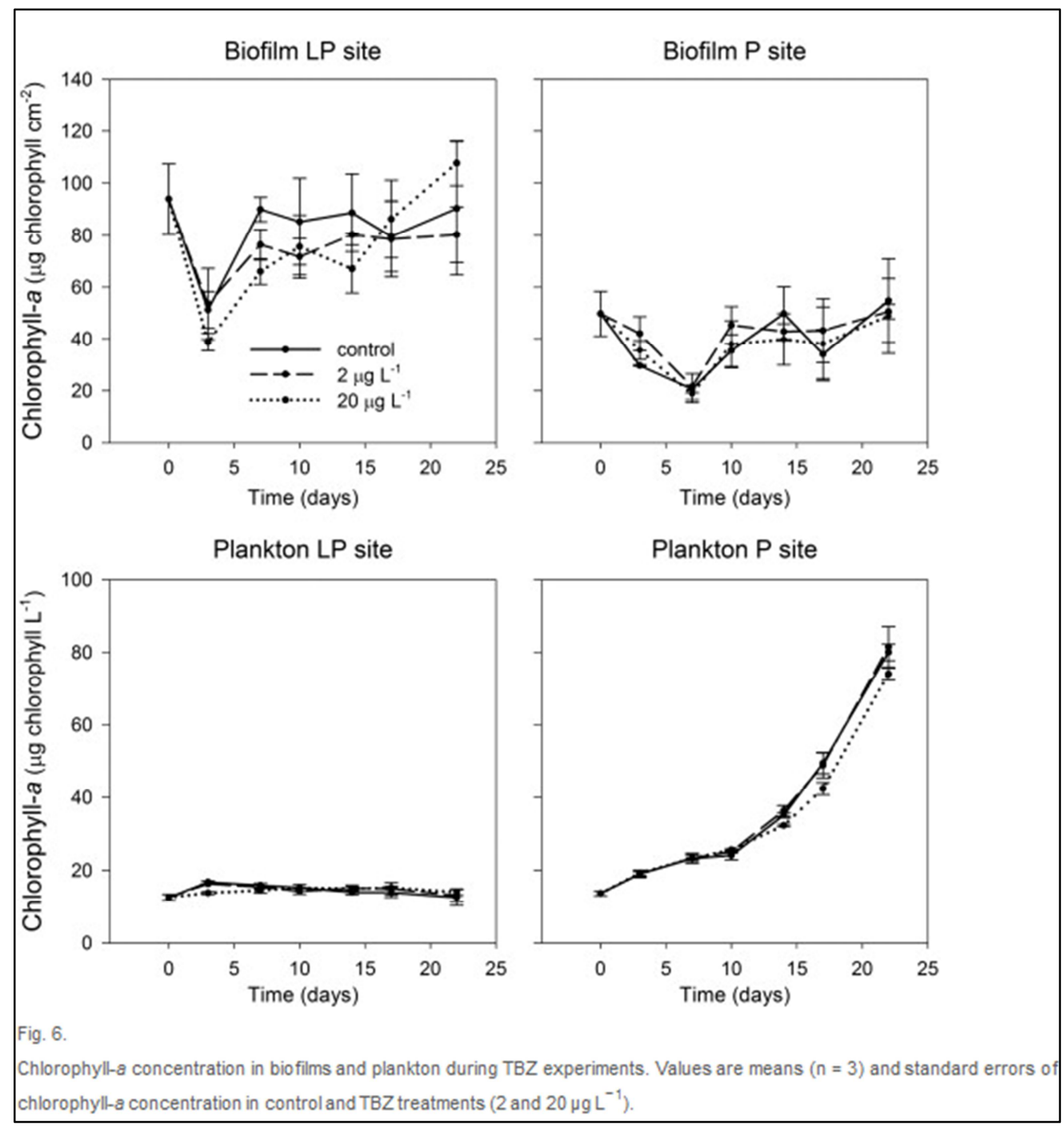

\subsubsection{Photosynthetic efficiency}

Photosynthetic efficiency (YII) values in control treatments stayed constant for biofilms $(0.58 \pm 0.01$ LP site, $0.56 \pm 0.008 \mathrm{P}$ site) and plankton communities ( $0.42 \pm 0.03 \mathrm{LP}$ site, $0.52 \pm 0.01 \mathrm{P}$ site) over the 22 days of the experiment. TBZ only had a detectable effect on YII in LP-site biofilms (Site $\times$ TBZ effect; Table 1, Fig. 7), which experienced a stronger decrease in YII at the higher TBZ dose treatment $(-11 \%$ on average) than at the lower TBZ dose $(-5.3 \%)$ (Tukey test, $\mathrm{P}<0.05)$. These decreases were especially marked at the end of experiment between Time 17 and Time 22 ( Fig. 7). Conversely, TBZ had no effect on YII in P-site biofilms or LP- and P-site plankton communities. 


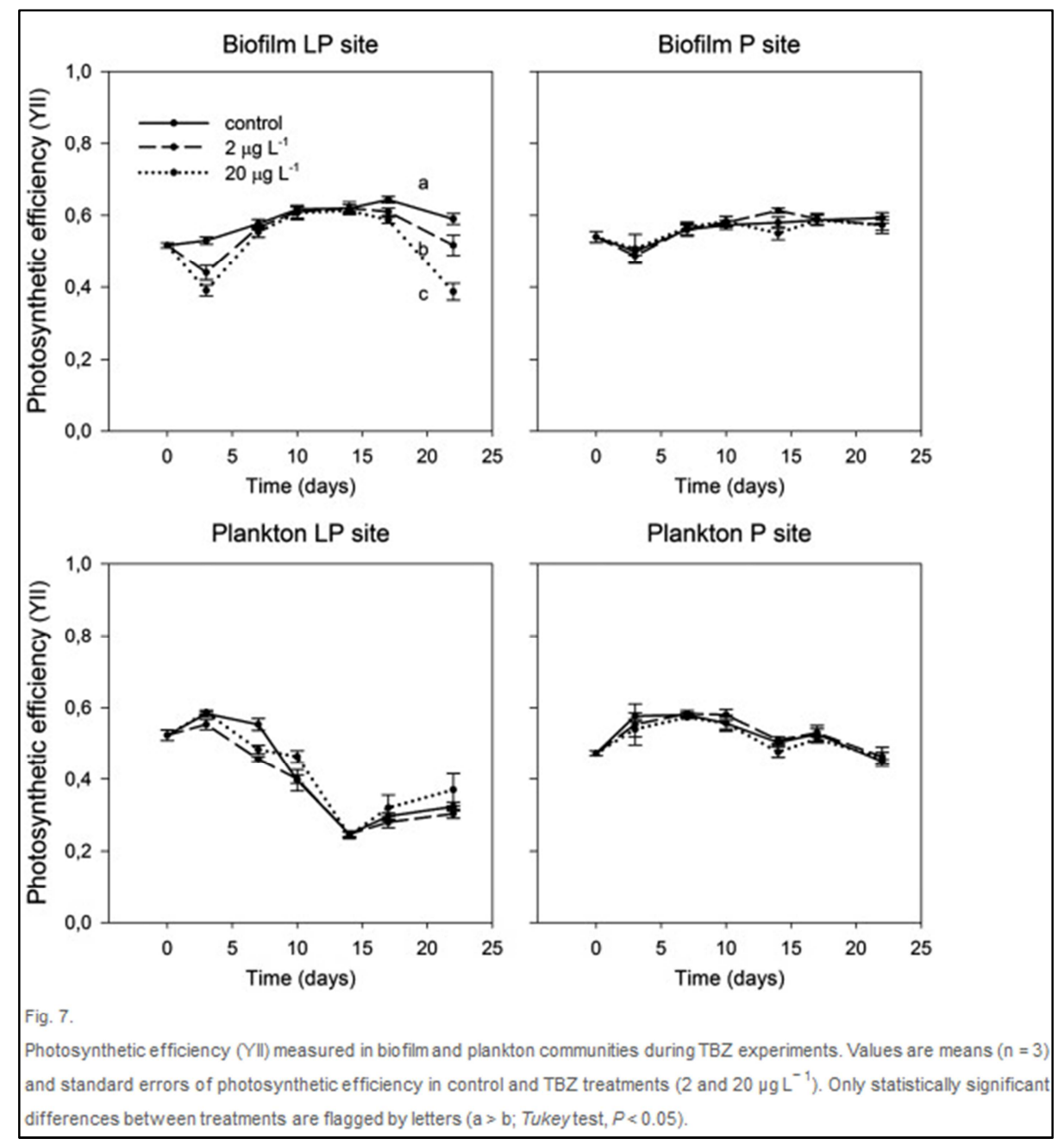

\section{Discussion}

This research has shown that biofilm and plankton microbial communities exposed to TBZ displayed different responses in some of the biological variables measured, suggesting that the effects of TBZ are modulated by lifestyle (benthic versus planktonic) and pre-exposure to pollutants (less polluted versus polluted).

Biofilm communities experienced functional alterations in presence of TBZ, as shown by a significant decrease in SIR and photosynthetic activity, especially in communities from the LP site. SIR inhibition might be partly explained by a direct TBZ effect on fungal activity in the biofilm (Table 2), as has been reported for soil microbial communities (Muñoz-Leoz et al., 2011). The observed decrease in SIR may be due to the death of fungi suggested by the increase in water DIN concentrations (Cycoń et al., 2006). Unfortunately, fungal biomass was not measured in this experiment, so we are unable to assess the proportion of dead fungi affecting SIR in biofilms. However, other studies support this view. For example, significant decreases in fungal biomass have been observed in benthic assemblages exposed for several weeks to TBZ concentrations (Bundschuh et al., 2011 and Artigas et al., 2012).

Interestingly, the reduction of SIR in biofilms coincided with increases (day 3 to 10) in bacterial cell mortality (L/D cell ratio), which also suggests a possible direct toxic effect of TBZ on bacterial community. In the same way, TBZ also impaired the photosynthetic efficiency of biofilms from the less polluted site. This effect was probably indirect (given the mode of action of TBZ; Copping and 
Hewitt, 1998) and could be the result of indirect effects of pesticides on the relationships between biofilm components (Ricart et al., 2009). Previous studies have reported that the herbicide diuron affected both algal and bacterial activity in biofilms, suggesting that pesticides may cause a chain effect in biofilms (Ricart et al., 2009). The effects on algae and bacteria observed here might result from direct effects of TBZ on fungal communities and possibly effects on protozoa (Table 2). Conversely, biofilm communities from the polluted site showed more variable responses to TBZ without any significant influence on the biological parameters measured. This finding suggests that these biofilms that were pre-exposed to TBZ and to other types of fungicides (see Montuelle et al., 2010) may have developed adaptational capacities leading to an enhanced tolerance to the TBZ molecule (or "pollution-induced community tolerance"; Blanck, 2002), as already observed in biofilms for other types of pesticides (i.e. the herbicide diuron; Tlili et al., 2011a).

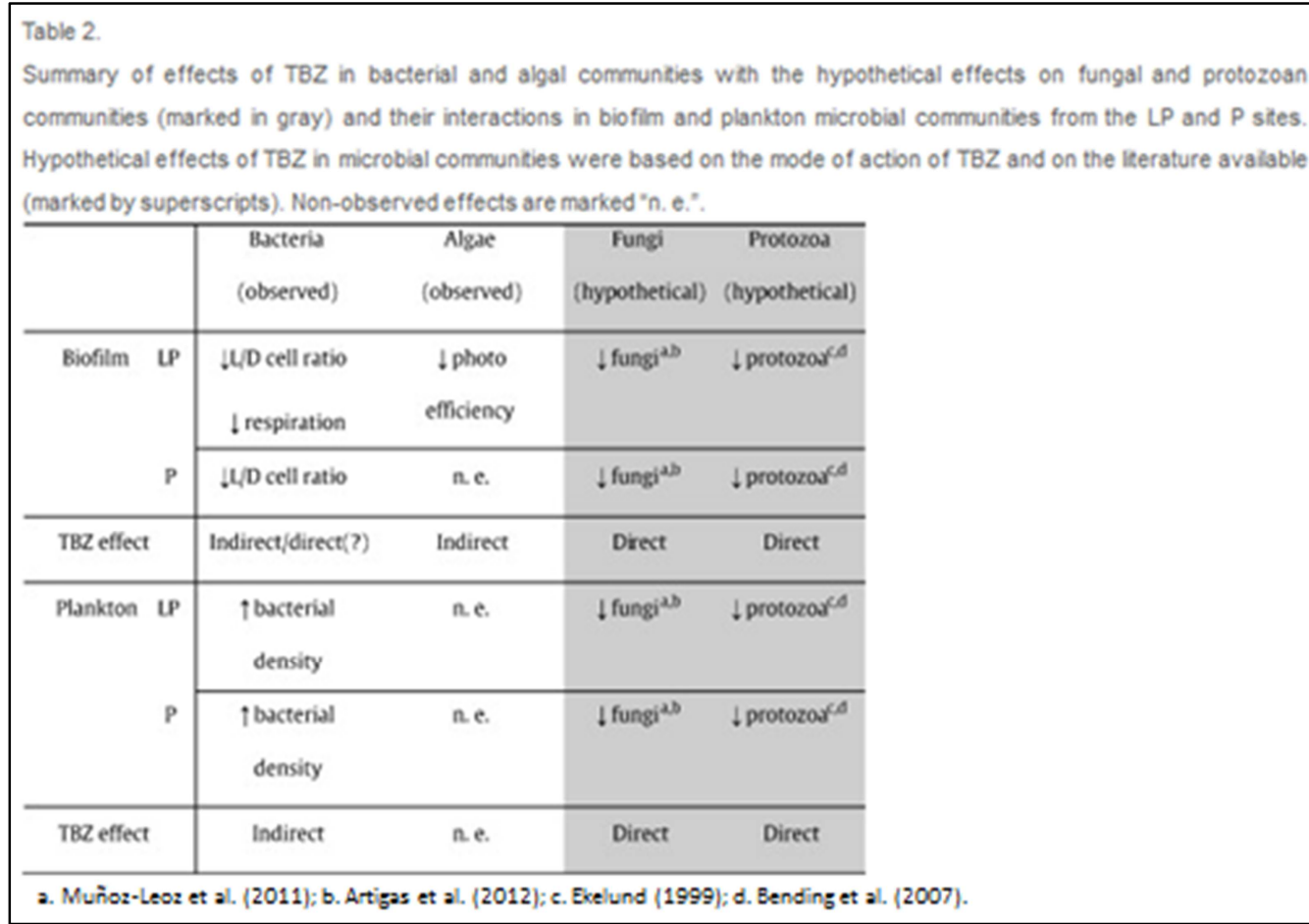

Conversely to biofilms, plankton communities showed a stimulation of bacterial densities in the presence of TBZ. This response was similar between plankton communities from LP and P sites and could be explained by (i) increased levels of nutrients and energy sources released from dead fungi (mostly unicellular forms in plankton; Wurzbacher et al., 2010) and utilized by bacteria, ii) direct TBZ effects on the protozoan community (Ekelund, 1999) reducing grazing pressure on the bacterial community, and iii) possible use of TBZ as an extra carbon source by the bacteria. The first two hypotheses are linked to the interaction between plankton microorganisms. For instance, grazing by protozoan communities is one of the major drivers shaping bacterial community structure in plankton (Güde, 1989). Studies using culture-dependent methods have shown direct reduction of protozoan populations by a variety of fungicides (Ekelund, 1999). Therefore, it cannot be excluded that direct negative effects of fungicides on bacterial grazers occurred in our microcosms, indirectly resulting in increased bacterial densities in the plankton communities (Table 2). The third hypothesis, concerning the microbial decay of TBZ, can be ruled out, since the carbon supplied by TBZ $(0.00125 \mathrm{mgC} \mathrm{L}-1$ and $0.0125 \mathrm{mgC} \mathrm{L}-1$ in the 2 and $20 \mu \mathrm{g} \mathrm{L}-1$ treatments, respectively) was between two and three orders of magnitude below DOC levels in plankton microcosms $(2.5-3.5 \mathrm{mg} \mathrm{C} \mathrm{L-1)}$ and was thus relatively unimportant. 
The different effects of TBZ between biofilm and plankton communities could be explained by difference in the nature of microbial communities, pre-exposure to TBZ, and possibly also the specific composition of microbial communities. The pyrosequencing approach employed here on $16 \mathrm{~S}$ and $18 \mathrm{~S}$ rDNA genes revealed that TBZ mostly affected the eukaryotic community and that this effect was different between biofilms and plankton (Pascault et al., in prep.). These pyrosequencing results supported our argument that the TBZ-induced reduction in protozoan populations might have led to increased bacterial densities in the plankton experiments. Bending et al. (2007) also found that the effects of TBZ on fungal and protozoan community structure differed in soils with identical mineralogical composition but different microbial community composition. Apart from community composition, the presence of EPS matrix in biofilms could also have modulated the effects of TBZ compared to plankton (free-living organisms) which is left more exposed to TBZ. This hypothesis is supported by previous work performed with metal contaminants. Indeed, metal toxicity is usually found at higher concentrations in biofilms than free-living organisms, since the structure of biofilms reduces solute penetration into the cells (Guasch et al., 2010). However, the duration and frequency of contamination episodes play a major role, since toxicant diffusion within the biofilm is influenced by exposure time (Guasch et al., 2010). Given the exposure mode, it is reasonable to posit that biofilm (adapted to peak exposure scenarios, at higher TBZ concentrations in this study) and plankton (more adapted to chronic exposure, at lower TBZ concentrations in this study) microbial communities have developed different strategies to cope with contaminants in their ecosystems, but this remains a speculation that needs to be tested.

The attenuation kinetics of TBZ differed significantly between biofilm and plankton experiments, being four times greater in biofilms. Several factors can be put forward to explain the observed differences in TBZ attenuation, including adsorption processes and biotic degradation of the molecule. Previous studies indicate that TBZ is a relatively lipophilic molecule (log Kow $=3.7$; Margni et al., 2002) that rapidly adsorbs onto organic matter ( Artigas et al., 2012). Biofilms possess a matrix of extracellular polymeric substances (EPS) capable of rapidly adsorbing metal ions ( Guasch et al., 2010) and organic matter ( Freeman and Lock, 1995), including organic pesticides such as TBZ. Conversely, plankton cells are mostly free-living and so develop less EPS, which would mean that they have a lower pollutant adsorption capacity. Another possible explanation could be microbial decay of TBZ ( Obanda and Shupe, 2009), since TBZ degradation metabolites (e.g. hydroxyltebuconazole and desbutyl-tebuconazole) were detected in water samples from biofilm experiments but not in samples from plankton experiments. However, the steep slopes observed in TBZ dissipation curves from biofilms suggested that an active sorption process took place between days 0 and 3 of experiment ( $\sim 50 \%$ of total TBZ dissipated). This process may mirror that described for other organic contaminants in biofilms where two sorption phases are identified - a rapid initial process to an "equilibrium" concentration and a second phase of slower sorption (Wicke et al., 2007). Consequently, it can be argued that TBZ was mostly adsorbed by the EPS matrix rather than degraded by microorganisms, and that this potential to adsorb TBZ was greater in biofilms than in plankton communities.

The different sensitivity between communities from LP and P sites could be explained by the differences in pollution-induced community tolerances of biofilm and plankton microorganisms to TBZ. Blanck (2002) postulated that toxicants exert a selection of sensitive species which get replaced by more tolerant species in biological communities. This principle concord with the contrasting responses to TBZ observed between biofilm communities from LP and P sites, but not for the plankton. The similar sensitivity to TBZ between P-site and LP-site plankton communities might be explained by the elevated TBZ concentrations used in our experiment, as the nominal concentrations 
of 2 and $20 \mu \mathrm{g}$ TBZ L- 1 can be encountered during contamination peaks in rivers but not in the lakes studied (mean TBZ concentration of $0.001 \mu \mathrm{g} \mathrm{L}-1$ in the polluted lake). Therefore, the responses observed in our plankton experiments should be considered as extreme scenarios of TBZ contamination. Finally, increasing the TBZ dose (from 2 to $20 \mu \mathrm{g} \mathrm{L}-1$ ) did not significantly enhance TBZ effects on biofilm and plankton community descriptors. Therefore, the toxicity of TBZ for the four types of aquatic microbial communities analyzed was detectable at a relatively low concentration ( $2 \mu \mathrm{g} \mathrm{L}-1$ in this experiment). A dose-dependent response is usually expected in toxicity experiments, but many exceptions are observed, as in the case of indirect effects in complex biological communities like biofilms (bearing multiple microbial interactions) where the effects of a toxic compound do not necessarily increase linearly with pesticide dose (Ricart et al., 2009).

\section{Conclusions}

TBZ effects in biofilm and plankton microbial communities were moderate at the 2 and $20 \mu \mathrm{g} L-1$ TBZ doses tested, which suggests that the actual TBZ concentrations found in the ecosystems pose relatively little ecotoxicological risk to the ecology of aquatic microbial communities analyzed. However, we found different sensitivities to the TBZ molecule between biofilms and plankton, which can be explained by the specific structure and composition of the microbial community. TBZ effects on non-targeted microalgal and bacterial communities were mostly indirect (Table 2) and seemed to be related to the multiple interactions between biofilm components (i.e. fungal and protozoan communities), though these results need to be confirmed by further investigations specifically targeting those microbial groups ( Pascault et al., in prep.).

TBZ toxicity assessment in aquatic ecosystems cannot be exclusively based on single-species responses but should also cover the responses of complex microbial communities (including targeted and non-targeted organisms) to the fungicide. Our study suggests that lifestyle (benthic versus pelagic), pre-exposure to TBZ (less-polluted versus polluted sites) and exposure mode (peak exposure versus chronic exposure scenarios) of microbial communities can accentuate the variability in microorganism responses to the TBZ fungicide. To improve TBZ risk assessment in aquatic microbial communities, further research should be performed by enlarging the spatial and temporal scale of microbial responses to TBZ.

\section{Conflict of interest}

We state that this manuscript does not entail any conflict of interest.

\section{Acknowledgments}

This study was funded by the Sendefo project under the French ANR [National Research Agency] Contaminants-Ecosystems-Health (CES-2009) program. The authors thank the Irstea Water Chemistry Laboratory in Lyon for running the chemical analyses and ATT for editing the English-language version of the manuscript. 


\section{References}

Artigas J, Majerholc J, Foulquier A, Margoum C, Volat B, Neyra M, et al. Effects of the fungicide tebuconazole on microbial capacities for litter breakdown in streams. Aquat Toxicol 2012;122123:197-205.

Bending GD, Rodriguez-Cruz MS, Lincoln SD. Fungicide impacts on microbial communities in soils with contrasting management histories. Chemosphere 2007;69:82-8.

Berenzen N, Lentzen-Gooding A, Probst M, Schulz H, Shulz R, Liess M. A comparison of predicted and measured levels of runoff-related pesticide concentrations in small lowland streams on a landscape level. Chemosphere 2005;58:683-93.

Blanck H. A critical reviewof procedures and approaches used for assessing pollution induced community tolerance (PICT) in biotic communities. Hum Ecol Risk Assess 2002;8:1003-34.

Bundschuh M, Zubrod JP, Kosol S, Maltby L, Stang C, Duester L, et al. Fungal composition on leaves explaINS pollutant-mediated indirect effects on amphipod feeding. Aquat Toxicol 2011;104:32-7.

Campbell CD, Chapman SJ, Cameron CM, Davidson MS, Potts JM. A rapid microtiter plate method tomeasure carbon dioxide evolved fromcarbon substrate amendments so as to determine the physiological profiles of soil microbial communities by using whole soil. Appl Environ Microbiol 2003;69:3593-9.

Chen SK, Edwards CA, Subler S. Effects of the fungicides benomyl, captan and chlorothalonil on soil microbial activity and nitrogen dynamics in laboratory incubations. Soil Biol Biochem 2001;33:197180 .

Copping LG, Hewitt HG. Chemistry and mode of action of crop protection agents. Cambridge, UK: The Royal Society of Chemistry; 1998. p. 160.

Cycoń M, Piotrowska-Seget Z, Kaczyńska A, Kozdrój J. Microbiological characteristics of a sandy loam soil exposed to tebuconazole and $\lambda$-cyhalothrin under laboratory conditions. Ecotoxicology 2006;15:639-46.

Ekelund F. The impact of the fungicide fenpropimorph (Corbel®) on bacterivorous and fungivorous protozoa in soil. J Appl Ecol 1999;36:233-43.

Freeman C, LockMA. The biofilm polysaccharide matrix: a buffer against changing organic matter supply? Limnol Oceanogr 1995;40:273-8.

Freese HM, Karste U, Schuman R. Bacterial abundance, activity, and viability in the eutrophic riverWarnow, Northeast Germany. Microb Ecol 2006;51:117-27.

Guasch H, Serra A, Corcoll N, Bonet B, Leira M. Metal ecotoxicology in fluvial biofilms: potential influence of water scarcity. In: Sabater S, Barceló D, editors. Water scarcity in the Mediterranean: perspectives under global change. The Handbook of Environmental Chemistry: Review SeriesSpringer; 2010. p. 41-53.

Güde H. The role of grazing on bacteria in plankton succession. In: Sommer U, editor.Plankton ecology. Succession in plankton communities. Berlin, Germany: Springer Verlag; 1989. p. 337-64. 
Johnsen K, Jacobsen CS, Torsvik V. Pesticide effects on bacterial diversity in agricultural soils - a review. Biol Fertil Soils 2001;33:443-53.

Kahle M, Buerge IJ, Hauser A, Müller MD, Poiger T. Azole fungicides: occurrence and fate in wastewater and surface waters. Env Sci Technol 2008;42:7193-200.

KolpinDW, Thurman ME, Goolsby DA. Occurrence of selected pesticides and their metabolites in near-surface aquifers of the midwestern United States. Environ Sci Technol 1996;30:335-40.

Le Jeune AH, Charpin M, Sargos D, Lenain JF, Deluchat V, Ngayila N, et al. Planktonic microbial community responses to added copper. Aquat Toxicol 2007;83: 223-37.

Margni M, Rossier D, Crettaz P, Jolliet O. Life cycle impact assessment of pesticides on human health and ecosystems. Agric Ecosyst Environ 2002;93:379-92.

Montuelle B, Dorigo U, Bérard A, Volat B, Bouchez A, Tlili A, et al. The periphyton as a multimetric bioindicator for assessing the impact of land use on rivers: an overview of the Ardières-Morcille experimental watershed (France). Hybrobiologia 2010; 657: 123-41.

Munawar M, Dermott R, McCarthy LH, Munawar SF, van Stam HA. A comparative bioassessment of sediment toxicity in lentic and lotic ecosystems of the North American Great Lakes. Aquat Ecosyst Health Manag 1999; 2:367-78.

Muñoz-Leoz B, Ruiz-Romera E, Antigüedad I, Garbisu C. Tebuconazole application decreases soil microbial biomass and activity. Soil Biol Biochem 2011;43:2176-83.

Obanda DN, Shupe TF. Biotransformation of tebuconazole bymicroorganisms: evidence of a common mechanism. Wood Fiber Sci 2009;41:157-67.

Pascault N, Artigas J, Roux S, Tadonleke RD, ter Halle A, Mailhot G, et al. Impact assessment of tebuconazole (fungicide) on bacterial communities from lake and stream ecosystems by a 16S rRNA pyrosequencing approach. 2013. In prep.

Pesce S, Batisson I, Bardot C, Fajon C, Portelli C, Montuelle B, et al. Response of spring and summer riverine microbial communities following glyphosate exposure. Ecotoxicol Environ Saf 2009;72:1905-12.

Porter KG, Feig YS. The use of DAPI for identifying and counting aquatic microflora. Limnol Oceanogr 1980;25:943-8.

Rabiet M, Margoum C, Gouy V, Carluer N, Coquery M. Assessing pesticide concentrations and fluxes in the stream of a small vineyard catchment: effect of sampling frequency. Environ Pollut 2010;158:737-48.

Rasmussen JJ,Wiberg-Larsen P, Baattrup-Pedersen A, Monberg RJ, Kronvang B. Impacts of pesticides and natural stressors on leaf litter decomposition in agricultural streams. Sci Total Environ 2012a;416:148-55.

Rasmussen JJ, Monberg RJ, Baattrup-Pedersen A, Cedergreen N,Wiberg-Larsen P, Strobel B, et al. Effect of a triazole fungicide and a pyrethroid insecticide on the decomposition of leaves in the presence or absence of macroinvertebrate shredders. Aquat Toxicol 2012b;118:54-61. 
Reilly TJ, Smalling KL, Orlando JL, Kuivila KM. Occurrence of boscalid and other selected fungicides in surface water and groundwater in three targeted use areas in the United States. Chemosphere 2012;89:228-34.

Ricart M, Barceló D, Geiszinger A, Guasch H, López de Alda M, Romaní AM, et al. Effects of low concentrations of the phenylurea herbicide diuron on biofilm algae and bacteria.Chemosphere 2009;76:1392-401.

Richardson SD. Water analysis: emerging contaminants and current issues. Anal Chem 2009;81:464577.

Rysgaard S, Kühl M, Glud RN, Hansen JW. Biomass, production and horizontal patchiness of sea ice algae in a high-Arctic fjord (Young Sound, NE Greenland).Mar Ecol Prog Ser 2001;223:15-26.

Schreiber U, Müller JF, Haugg A, Gademann R. New type of dual-channel PAM chlorophyll fluorometer to highly sensitive water toxicity biotests. Photosynth Res 2002;74:317-30.

Simmons DBD, Wallschlager D. A critical reviewof the biogeochemistry and ecotoxicology of selenium in lotic and lentic environments. Environ Toxicol Chem 2005;24:1331-43.

Strickland TC, Potter TL, Joo H. Tebuconazole dissipation and metabolism in Tifton loamy sand during laboratory incubation. Pest Manag Sci 2004;60:703-9.

Tadonléké RD, Planas D, Lucotte M. Microbial food webs in boreal humic lakes and reservoirs: ciliates as a major factor related to the dynamics of the most active bacteria. Microb Ecol 2005;49:325-41.

Tadonléké RD, LeBerre B, Perreau F, Humbert JF. Responses of lake bacterioplankton activities and composition to the herbicide diuron. Aquat Toxicol 2009;94:103-13.

Tlili A, Montuelle B, Bérard A, Bouchez A. Impact of chronic and acute pesticides exposures on periphyton communities. Sci Total Environ 2011a;11:2102-13.

Tlili A, Marechal M, Montuelle B, Volat B, Dorigo U, Bérard A. Use of the MicroResp ${ }^{\mathrm{TM}}$ method to assess pollution-induced community tolerance tometals for lotic biofilms. Environ Pollut 2011b;159:18-24.

Wicke D, Böckelmann U, Reemtsma T. Experimental and modeling approach to study sorption of dissolved hydrophobic organic contaminants to microbial biofilms. Water Res 2007;41:2202-10.

Wurzbacher CM, Bärlocher F, Peter-Grossart HP. Fungi in lake ecosystems. Aquat Microb Ecol 2010;59:125-49. 